\title{
Research on the Construction of Digital Library in Colleges and Universities in China
}

\author{
Limei Tian ${ }^{1, a}$ \\ ${ }^{1}$ Library, Bohai University, Jinzhou, Liaoning, China \\ aMacy521_2006@163.com
}

Keywords: University; Digital Library; Construction.

\begin{abstract}
In this paper, the construction of digital library in China academic is considered as the research subject by introduction of the digital library, leads to the important practical significance of the construction of University Digital Library, and five important sector of the construction of Digital Library in detail, finally puts forward the construction of University Digital Libraries in China should pay attention to five problems. We hope that through this study, We can provide some help and inspiration for the professional research of relevant experts and scholars.
\end{abstract}

\section{Introduction}

At present, taking technology of the computer as the main representative of the rapid development of high technology, the dissemination of information, the information carrier, information storage and so on are inseparable from the support of network technology and digital technology, digital information trend has begun to bring profound change to the education and teaching in Colleges and Universities, especially in the construction of Library of colleges and universities faced not only changes in the pattern of, is also facing the change of the direction of development. Therefore, the creation of digital library planning, is conducive to the self construction, but also conducive to the improvement of the comprehensive ability and level of education and teaching.

\section{Digital Library}

Digital library is based on the network to digital form for storage and processing of information and through the network users in different locations to provide digital information service system. It can not only realize information digital, but also can help the literature information transmission network, but also help document information so that everyone shared. Through the three significant characteristics, can maximize the help people search, read, download and share all kinds of real-time and historical information.

\section{Significance of the construction of Digital Library in University}

Improve the quality of education and teaching. Through the construction of digital library to help educate management step on a higher level, on the one hand to from the point of view of information management to provide more economic, more scientific, more convenient service configuration, reduce the cost of information management, on the other hand, can help schools raise to the student education resources to maximize the protection, effectively extend outside the classroom learning space, really improve the depth and breadth of the education content.

Create a good internal learning atmosphere. Network and the construction of information platform to attract the attention of young students, in the school does not have its own educational function and build the information interaction platform, virtually formed within the school of communication network, to create a good internal learning atmosphere to help larger. Practice has proved that: high digital degree of the University Library, the usage rate, praise and attractive more prominent. 


\section{Five important points in the construction of Digital Library}

Construction of digital document database library. Digital library construction is the cornerstone of the construction of Digital Library of rich content, various forms, distinctive characteristics of the digital resources of digital library is to provide quality, efficient, convenient service guarantee, therefore, colleges and universities in the construction process, must have the plan, planning, construction of digital resources of digital library information service system implementation steps the introduction, including a foreign language in the large database, building its own resources database and the development and utilization of Internet resources in three aspects. Specifically: first, by paying for direct purchase, buy some in line with their own education characteristics, meet the students' need, in line with a large database of resources for future development needs, improve discipline the inner core competitiveness; two is the depth of mining and improve the natural resources of Museum group, can make internal force by competent group Amount of backtracking construction, can also according to the characteristics and advantages of the project of the University for special construction, for the development of the subject and its teaching and research precipitation make the active adjustment; the third is to give full consideration to the richness of the information network, establish and improve the key discipline navigation database, through effective means and channels will be online rich information resources of virtual library collection, for students to use the network information resources in the fast lane.

Application platform construction of Digital Library. Construction of a digital library application platform is very important, it is internal processes to facilitate the management, but also for internal cost control management to provide help. Automation integrated management technology application, the navigation system, system integration, system application of the organic link up and optimize the quality control process.

According to the transformation, the students through the FAQ, mail and other real-time interactive text, multi way and reference librarian contact, real-time problem solving. Through adjustments, the students can be in the search process achieve rapid retrieval, save time and improve efficiency. Through ascension, students can more convenient sense have intelligent platform to bring help. In addition, digital resources create system construction and application, can the college oneself characteristic resources posted online, to provide a channel to further expand the influence of the school.

The construction of the supporting platform. The supporting platform construction, which mainly covers the following aspects of construction content: one is internal network construction of university library, the network is divided into network query, business network, office network, network VOD, network application service private network, such as the; the second is the construction of university library storage system, through the optical disk array system and SAN architecture, settled between spatial data, system, the gap between media collocation, to enhance the data operation speed and efficiency.

The construction work of the firewall. University Digital Library Network Firewall construction work is essential a part by strengthening the digital library of the firewall technology, anti-virus technology and safety management system technology research and application, to prevent the database is hackers sabotage and theft of network information resources. The case, using a set of mature, stability, security, the network security management measures to reduce the operation of various types of emergencies, a comprehensive solution to the worries.

The construction of the service environment. Provide a friendly interface, convenient operation, portal website of digital library function is configured properly, not only can reflect the image of the library from the outside, also to further strengthen internal relations between users and the library. First, through the organization design, series of work allocation professionals responsible for website construction, special attention should be paid by the research found the scheme meets the personalized demand, and maintain innovation adjustment and optimization function; second, accelerate the construction of university library information collection, management and deployment of construction, to provide convenient services for the teachers and students on the one hand, on the other hand, to provide convenient services for outside information users; third, digital library should 
use the advantage of the network to carry out publicity and education of users on the Internet, introduces the library integrated system, directory query system, electronic reading room to use. Students to teach the use of domestic and foreign databases and network information resources, to carry out the information literacy education for the user, to play a library of educational functions.

\section{Five problems in the construction of Digital Library in Colleges and Universities}

Digital library construction in Colleges and universities started relatively late, many specific aspects of the work is still in initial stage, both material resources, financial resources, human or from the energy, intelligence, there are considerable challenges. Therefore, starting from the concrete practice process and need to pay attention to avoid the following several problems:

First, strengthen the requirements of standardization in the construction of digital library, the standardization process, in-depth study of the standardized management, to avoid the non standard possible construction;

Second, to the existing network technology, information talents, information resources, and makes a reasonable allocation of funds and facilities such as power, avoid project the investment, construction duplication and waste;

Third, pay attention to the protection of intellectual property in the construction process;

Fourth, to carry out a variety of business skills of staff training, especially to strengthen the application of computer and network knowledge training, at the same time, should also be the introduction of a number of both computer, network, multimedia and other modern the technology of high level talents, but also to carry out research and development of various software, to adapt to the development of the digital library;

Fifth, through the students training, continuing education, providing online self-study and online help And so on, to introduce students to the network environment, the way to use information to help students to grasp the retrieval, access, the use of useful information to improve the student's modern information awareness and information skills.

\section{Acknowledgment}

This research is supported by the Key project Social Science Association of Jinzhou (B\&R strategic countermeasures to promote the development of Marine economic of Jinzhou).

\section{References}

[1] Dou J, Zhao X L. Research on the Construction and Service of Digital Library in High Vocational College[J]. Journal of the Library Science in Jiangxi, 2012.

[2] Zaniewska M, Mccreary A C, Wydra K, et al. Strategy Management Research on Digital Library Construction in Colleges and Universities[J]. Journal of Medical Informatics, 2010, 64(7):511-519.

[3] Yuan Y, Qing-Jiang L U. Thoughts on the Construction of Digital Library in Colleges and Universities[J]. Journal of Chongqing University of Science \& Technology, 2006.

[4] Chen X C. Talking about the Construction of the Digital Library in Colleges and Universities[J]. Sci-Tech Information Development \& Economy, 2006.

[5] Yin D, Zheng J. Research on the Construction of Digital Library's Administration System and Management Mechanism in China[J]. Library Journal, 2011.

[6] Jian-Fang Y U. Discussion on the Present Situation and Construction of Characteristic Digital Resources of Digital Library Collections of Ethnic Universities and Colleges in Northwest China[J]. Modern Computer, 2014.

[7] Zhu Z F, Zhang X D, Zhu Y Q. Reflections on the Construction of Logistics Digital Resources Library in Colleges and Universities[J]. Value Engineering, 2014. 
[8] Li Y. Analysis and Research on the Co-construction and Sharing of Hunan Academic Digital Library[J]. Library Work in Colleges \& Universities, 2015. 